\title{
POST-SECULARISM AS A BASIS OF DIALOGUE BETWEEN PHILOSOPHY AND RELIGION
}

\section{Otto Gusti Ndegong Madung}

Ledalero Catholic School of Philosophy, Flores, Indonesia

Email: ottomadung@hotmail.com

\section{Abstrak}

Tulisan ini bertujuan untuk membahas persoalan radikalisme agama. Radikalisme agama di sini ditafsir sebagai protes atas patologi sekularisme yang ditandai dengan peminggiran agama ke ruang privat. Privatisasi agama adalah sebuah proses yang menempatkan agama di ruang privat yang irasional dan karena itu agama dianggap tidak dapat berpkiprah di ruang publik yang plural. Sebagai solusi tulisan ini menawarkan paradigma post-sekularisme dari Juergen Habermas yang membuka ruang bagi partisipasi publik agama. Lebih jauh, tulisan ini berargumentasi bahwa dalam masyarakat post-sekular di mana agama kembali muncul di ruang publik, perlu dibangun dialog yang rasional dan demokratis antara agama dan akal budi. Jembatan yang menghubungkan keduanya adalah nalar publik. Kondisi post-sekularisme ini membuka peluang bagi teologi untuk memajukan toleransi dalam masyarakat plural dan memperkuat keterlibatan agama atau Gereja di ruang publik, sehingga agama tidak direduksi kepada kesalehan privat minus pertanggungjawaban publik, melainkan terlibat secara sosial-politis dalam proses pembebasan kelompok marginal.

Kata kunci: Post-Sekularisme, Filsafat, Agama, Sekularisasi, Radikalisme

\section{Abstract}

This article tackles the problem of religious radicalism. Religious radicalism is here interpreted as a protest against the pathology of secularism characterized by the privatization of religion. The privatization of religion is a process in which religion is regarded as an irrational and personal element, so that it cannot play a public role. In order to meet the pathology of privatization, this article offers the paradigm of post-secularism as 
proposed by Juergen Habermas that opens up the possibility for religion to actively participate in the public sphere. Furthermore, this writing argues that in post-secular society characterized by the public role of religion, it is essential to build a democratic and rational dialogue between religion and philosophy, faith and reason. A bridge that connects both is public reason. This article also shows that the post-secular condition opens up opportunities for theology to promote tolerance in a pluralistic society and to strengthen the public engagement of religion. This can avoid reducing religion to private piety without public responsibility while promoting the public engagement in religion in order to liberate the marginalized and oppressed.

Keywords: Post-Secularism, Philosophy, Religion, Secularization, Radicalism

\section{INTRODUCTION}

On $8^{\text {th }}$ April 2017 the former Chairperson of the Muhammadiyah Organization, Ahmad Syafii Maarif, said the following: "Theology of death, daring to die because it does not dare to live, monopolizes the truth that is not legitimate outside of us" (Madung, 2017). With the concept of theology of death Syafii Maarif expressed his concern for a phenomenon of religious radicalism that neglects the principle of tolerance and living together in a pluralistic society. Furthermore, the spread of theology of death can threaten the national unity of Indonesia. This concern of the former Chairperson of the Muhammadiyah Organization has become a threat to the common life structure of the Indonesian people. The plurality of religious beliefs is no longer interpreted as a source of enrichment, but rather as a deviation or something that is not legitimate, which must be dealt with using the concept of a monopoly of the truth.

This threat to diversity is not limited to the field of ideological discourse regarding the monopoly of truth. Those carrying the coffin of pluralism are not afraid to use thuggery and physical violence in the public arena. This can be seen in data regarding the growing number of cases of intolerant behaviour and violence towards minority groups in Indonesia. On 31 ${ }^{\text {st }}$ March, 2019, the 
SETARA Institute publicly documented 160 cases of abuse against the freedom of religion and beliefs during 2018 in Indonesia. Those 160 cases involved 202 offensive actions by either the state apparatus or elements in society. This is an increase on the previous year, 2017, which experienced 155 cases with 201 actions (Rahman, 2019).

This data clearly shows that the responsibility of the state to guarantee the freedom of religion or belief of its citizens is far from being put into practice. Threats to such freedom are made more serious by the phenomenon of right-wing populism that has come to the fore in Indonesian democracy over the past six years. This can be seen clearly in the prominence of conservative religious morality in discourse and political activity (Hadiz, 2017). The influence of the conservative interpretation of religious teachings is evident in the way the private rights of citizens (liberal rights) are ignored, particularly those at the edge of society such as the LGBT community, and this strengthens the anti-liberalism tendency in Indonesian democracy (Madung, 2020).

In this regard, it will be emphasized that an approach that is solely focused on security and the implementation of the law, is not sufficient to overcome the spreading of a doctrine of the theology of death. Promoters of the theology of death cannot simply be seen as proponents of violence. They are also victims of the multidimensional crisis which is presently hitting Indonesia. This crisis has been caused by problems of poverty, corruption, the gap between the rich and the poor, as well as the unjust distribution of wealth.

This article will focus on the theoretic basis, by referring to a number of social thinkers who state that the movement of fundamentalist religion and terrorism is correlated to a multidimensional crisis which is being faced by modern society. An important sociologist at the beginning of the $20^{\text {th }}$ century, Max Weber (1864-1920), for example, described the development of modern, secular society as being identified by the privatization of religion and a crisis of values. According to Weber, the crisis of 
values happened because in modern society religion lost its public role in identifying moral values. This crisis is a reaction to the process of secularization which is itself identified by the development of a process of the rationalization of life, as is impacted by the dominance of instrumental rationality which is characterized by efficiency. In the category of efficiency and the domination of science, religion, mythology and questions about values do not have a place in the arena of rational discourse. These are seen as matters regarding personal salvation. A balanced and democratic dialogue between science and religion, between common-sense and faith, does not take place.

This article proposes the need to go past secularism and build a post-secular paradigm, by opening a venue of communication between common-sense and theology, between common-sense and faith, as a way which could be followed to weaken the flow of the spread of the theology of death. Institutionally, this mode of dialogue can be practised, and has indeed already been undertaken, by theological faculties in Indonesia. The role of the state is to support such efforts and to guarantee that there will always be a condition of academic freedom, in accord with current international standards. In this way, the privatization of piety which has become a characteristic of the theology of death, can be transformed to become a post-secular theology which emphasizes public religious practice. Here, religion will actually supersede private piety and become a source of inspiration which can overcome ethical, social and moral problems which threaten society.

The text is divided into several parts. The first section gives an understanding of secularization from a historical and substantive perspective. The second section focuses on the crisis of the secular paradigm, and the birth of post-secularism as an answer to that crisis. The third section posits two relevant theological points coming from a critique of secularism which has given birth to the paradigm of post-secularism. 


\section{AN UNDERSTANDING OF SECULARIZATION}

\section{An Historical View}

Both terms, secularization and secularism etymologically are derived from the Latin word, saeculum, which means era. In the Christian Biblical tradition, particularly in the letters of the Apostle Paul, saeculum is used to describe the world which is controlled by sin. The same understanding was developed in the theology of the Fathers of the Church in the Middle Ages, who saw saeculum as a world filled with sin that needed to be shunned (Eicher, 1991).

This understanding provides the context for the term saecularizatio in Catholic Church Law (Canon Law), which means the process by which a fully-professed member of a monastery goes back into general society, or the world. Because of this, secularization also has the meaning, "a process of re-entering the world" (Verweltlichung). Since the Concordat of Westphalia (1648) which marked the end of the 30 year conflict between Protestants and Roman Catholics, which devastated much of Europe, the term secularization has had a political nuance. Since then, too, secularization also means the process of returning the wealth and institutions of the Church to public ownership which had been confiscated by the state following the Church's defeat (Lübbe, 2003).

Secularism is the most radical form of secularization. It shows an intellectual attitude which liberates someone from all religious influence, and views humankind as a profane being, or one that is solely worldly without any reference to the transcendental. Secularism as an ideology that is anti-religious first came to the fore in the mid-19th century (Eicher, 1991).

\section{A Contemporary Understanding}

After describing the historical dimension of secularization, this section poses two contemporary fundamental understandings of secularization. Firstly, secularization is understood as a process of dividing and emancipating the entire life of humankind from the context of the Christian faith. The human understanding of the 
world and humanity itself is expressed without reference to the values or paradigm of Christianity (Habermas, 2020). Secularization pictures the process of the disappearance of the view and eschatological religious system, and its replacement by a rational view which is oriented to the present, the power of nature, historical order and the autonomy of the individual (Ulfig, 1999). A consequence of this was birth of the view that humans are masters of themselves, nature and history. An important achievement for humanity's history has been the separation and the clear division between faith or revealed religion, and rational understanding based on experience. At the political level, secularization has given birth to the concept of the secular state, where there is a division between religion and the state (Habermas, 2020). Religion is seen as being concerned with private matters pertaining to living a good life, while the state has responsibility for public affairs and maintaining justice. Secularization also means the de-sacralization of politics. Politics no longer refers to The Transcendent, as in a theocracy.

Sociologist Max Weber, describes secularization as being uniquely developed by European society, and is a special form of modernity. He identifies three important aspects of the process of secularization: Firstly, the dominance of positive law in the order of political authority. Secondly, the growth of the rationalization of life impacted by the domination of instrumental rationality which is characterized by efficiency. Thirdly, Entzauberung der Welt, "a disenchantment of the world" resulting from scientific criticism or the demythologization of a mythological/magical world.

Secondly, secularization expresses a process of the transformation of living, of language and of a Christian outlook, into a secular system without dependence on the transcendental. In addition to the three aspects mentioned in the previous paragraph, Max Weber has the view that secularization is also identified by a process of personalization or extreme individualization regarding certainties of belief which are taught in religions such as Calvinism. Through the formation of conscience and asceticism, this entire 
process is grown into individuality in modern society, and is expressed in capitalism as the mainstream economic system and the evolution of the modern bureaucratic state (Verwaltungsstaat) (Weber, 1988; Habermas, 2020).

So, according to Weber, secularization is not about getting rid of religion, but is a process of the transformation of religion, focusing on the human spiritual dimension (innerlich). However, Weber is conscious that in the journey of history, the process of rationalization throughout social order is coloured by the domination of instrumental rationality (economics, bureaucracy and technology). This pushes religion into the private sphere, to such an extent that it can seem to be irrational (Weber, 1988).

This view of Weber's has for a long time been the paradigm reference in understanding modern European culture and society. It would seem that there is a rationalizing of the living world and scientific advances which have pushed religion out of the public and into the private sphere. This sociological description has become the prescriptive norm to exclude religion from the public domain.

\section{THE CRISIS OF SECULARISM \& POST-SECULARISM}

These days, Weber's view of regarding secularization and the process of rationalization which characterized the development of modern society, attracts much criticism. An important criticism is that of Juergen Habermas. According to him, there are two mistakes in Weber's understanding of secularization (Habermas, 2001; Dew, 2019). Firstly, secularization is understood as Verdrängungsmodell, which means in modern society religion will disappear of its own accord, and will be replaced by science and the ideology of progress. This is Max Weber's position, which for a long time has been the scientific benchmark for the understanding of modern society.

Secondly, secularization is understood as Enteignungsmodell. This model pits modernity and secularization as the enemies of religion. The reason for this is because secularization is considered as the source of moral depravity (Carr, 2012). Several politicians want Indonesia to be a religious state. In this way, all the problems 
of the nation would come under this paradigm (Madung, 2021). According to Habermas, religious terrorists, particularly noting those who acted in the terrorist attack on $11^{\text {th }}$ September, 2001, have this understanding of secularization. They want to rebuild religious "morality" using violence. Habermas evaluates these two paradigms as being too narrow, and not in accord with the reality of a post-secular society, where religion and science can exist side by side.

What is post-secularism? Habermas describes post-secularism as a condition in which religion reappears in public sphere. In this way, post-secularism is a criticism to the idea of secularization that relegates religion to private realm. However, the contemporary resurgence of religion in public sphere is somewhat ambivalent. On the one hand, religion emerges violently in public realm in the form of religious fundamentalism and terrorism (Habermas, 2001). Religion appears on political scene in non-liberal ways. This kind of post-secularism considers the whole society as religious and declares secularism as a threat to the moral organized society. On the other hand, the resurgence of religion in public sphere is also expressed as a correction to the process of secularization. Postsecularism is here characterized by an epistemological distance from the assumptions of secularism (Dew, 2019). But it does not mean that we are living in some fully religious sphere without the secular.

It is very important to develop the concept of post-secularism for the context of Indonesia. Indonesia is multicultural and multireligious country. This condition of plurality is a richness for living together. However, as mentioned at the first part of this writing, the spear-head of a theology of death is threatening our national unity in diversity. Post-secularism can here provide a method for how religion in Indonesia actively participates in public space without threatening other religions, ideologies and concepts of a good life. Post-secularism encourages religion to be involved in public sphere and to simultaneously recognize the plural condition of the public sphere. 
Post-secularism is at once a revision of, and an answer to, the crisis of secular society. It stresses that modern society must go on taking into account the continuity of the life of religions. Religions continue to have an active role in directing social development (Dew, 2019). The role of religion is more evident when the road of the project of modernity is in danger of going off the rails (Entgleisung der Moderne). When this happens, religions can be agents which give meaning, and can be bearers of light which provide an ethical orientation for humanity (Madung, 2021).

Philosophically speaking, in secular society, one cannot explain why humanity must obey moral precepts if that obedience must be paid for by sacrificing one's own life. The question of why people should sacrifice their lives, for example, by opposing a totalitarian or repressive regime, to fight for the rights of fellow people who are oppressed, cannot be explained simply in a rational way (Madung, 2021). The constancy of faith in something transcendent is needed, which exceeds the transience of this world. Such a footing is only found in religion. Hans Küng, a Swiss-born Catholic theologian, formulates this well: "Notwithstanding men and women take responsibility to obey moral norms, one thing remains a person cannot do that without religion: That is to give a basis for the certainty and universality of moral obligations (Küng, 2008).

The crisis of the secular paradigm becomes clear when dealing with contemporary public moral problems, such as euthanasia, abortion and human cloning. Only by relying upon rational considerations, secular morality cannot stem the desire of terminally ill patients who want to end their lives ahead of time to stop the pain they are no longer able to bear. And why should the abortion of a child conceived by rape be opposed ethically? Challenges such as these are why philosophy in the post-metaphysic paradigm has begun to look to religion (Madung, 2021).

So that religion can have an emancipatory role in secular society, it must participate in the public arena and enter into dialogue with science. According to Habermas, the bridge which 
links these is common-sense which is rational and democratic (Habermas, 2001). It provides a middle way, neither biased towards science or religion, neither putting down one or the other. Commonsense needs to be open towards religion.

In order that every effort to create a rational consensus does not unfairly push religion to the edges of the public arena, and does not hamper the potentiality of religion to benefit secular society, the secularists must have an understanding of religious language (Miller, 2019). Also, because the boundary between science and religion is often cloudy, a willingness on both sides is needed to view issues from the other's perspective. Habermas has no desire to put aside religious meanings which have a secular potential, but he endeavours to translate these in a modern way.

What Habermas called "Rational Common-sense" in an article he wrote in 2001, entitled, "Glauben und Wissen", he articulated in later writings using the expression, "Public reason" (öffentliche Vernunft) (Habermas, 2005). Public reason takes into account the resource of the power of the intellect which can be accessed publicly in civil society, but is separate from the logical study of purely empirical science. The public reason is the antithesis of the scientism of Max Weber, and the relationship between empirical science and the process of secularization. In the light of public reason, religion is not necessarily viewed as something irrational or a private spiritual expression that axiomatically does not have the validity of theoretic truth and practical accuracy.

Public reason is the bridge which connects religion and common-sense as expressed in the title of his book, "Between Naturalism \& Religion" ("Zwischen Naturalismus und Religion"). As an arena, a communications media and the transposition between comprehensive doctrines (ideology, religion and a particular view of life), public reason is not only tied to political essentials, but also expresses the epistemological possibility of criticizing comprehensive doctrines from different viewpoints. This implicates the normative need for comprehensive doctrines to develop reflective methods of self-criticism. 
A discourse about post-secularism does not just have an empirical dimension, but is also normative (Lutz-Bahmann, 2015). The process of secularization can be seen both in developed and developing nations. The development of science, technology and modern civilization cannot ignore the relevance of religion, views of life, or comprehensive doctrines. In a normative way, postsecularism means that in the name of enlightenment and science, the influence of religion and comprehensive doctrine in society at large must go through a filtering process of public criticism, legally independent from national political activities.

Post-secularism does not totally reject the principle of secularization, but tries to correct the pathology of secularism. This means post-secularism presumes that principles of secularization such as the differentiation of social systems in modern society (religion, science, art, culture and law), acknowledgement of basic human rights, the separation of law and the democratic constitutional state on the one hand, and religion on the other, are recognized and guaranteed socially by the political institution. Sadly, though, it needs to be acknowledged that the principles of secularization are not yet universally accepted. This can have a negative effect on the development of civil society and the postsecular order which is in process. In modern society, postsecularism demands a process of communication, and mutual learning between religion and common-sense. This is formulated succinctly by Habermas, from the perspective of a religious person:

"Until the present day, religious traditions articulate something that is missing. They remind us of the importance of sensibility to defeat. Religion helps culture not to forget personal and social dimensions of life, in the midst of the hurly-burly of the progress of cultural and social rationalization which tends to be destructive." (Habermas, 2005)

However, this openness needs to be demonstrated by the followers of religions in a civil society which is characterized by pluralism with an acknowledgement of basic freedoms, an open 
culture, and science (Miller, 2019). For the importance of an epistemological position itself, religions are urged to translate their worldview into the language of public reason. Thus religious argumentation can be heard and responded to seriously in the democratic discourse of a civil society regarding public issues (LutzBahmann, 2015).

In order for religion to be able to translate its teaching into the language of public reason, internally a religious community needs a structural renewal which is open to the arena of the process of pluralization of internal religious views. Such an openness is certainly not the same as radical pluralism and its arbitrariness a la post-modernism which is closed to all possibilities of dialogue. Religions must critically reflect upon their history and doctrine. This critical reflection needs assistance from an historical critical method, critical semantics and hermeneutics (Lutz-Bahmann, 2015).

Quality reflection such as this will enable religions to speak in the public arena and participate in a learning process that goes on in the constellation of post-secular society. The danger of intolerance and religious fundamentalism can be avoided and rejected in the name of public reason (Lutz-Bahmann, 2015). Intolerance and fundamentalism will be obliterated when religion can formulate its points-of-view in the language of public reason, which goes above and beyond its original pre-political and primordial identity. It will then contribute towards the forming of a political and a posttraditional solidarity which can stand erect in a pluralist society. However, it is to be regretted that this has not yet happened in many countries, including Indonesia.

\section{POST-SECULARISM AS A BASIS OF DIALOGUE BETWEEN RELIGION AND PHILOSPHY}

\section{Religion and the Principle of Tolerance}

The religion which takes its place in the public arena as well as having the potential of translating into the language of public reason, can strengthen solidarity in a modern pluralist society (Carr, 
2012; Seljak, 2016). Dangers of sectarianism, intolerance and even religious fundamentalism can be overcome. Religion is no longer regarded as a source of conflict and a means of promoting one's exclusive ideology, but it can have a role promoting tolerance as a foundation stone for building a common, inclusive way of living.

Tolerance is essential when different ethical, religious and comprehensive doctrinal views are in conflict, where neither side is rationally able to prove that the other side has damaged what holds together life in common (Seljak, 2016). Despite there being a deep gap between the different stands, each person is able to value the other, based on the norms which they have agreed upon together, and not because of one side's opinion.

Post-secularism gives a venue for tolerance to be realized in a process of mutual learning between religion and secular reason. Common-sense should not be a biased judge of religious truths. It should, rather listen to religious claims in the public arena. So that they can be heard and understood in a pluralist public domain, religions need to be able to translate their doctrines into public common-sense language (Habermas, 1996). Habermas describes the process of mutual learning of religion and secularism in this way:

"The religious bloc must acknowledge the authority of 'natural' common-sense as being the result of work done by the scientific institution which can be falsified, and the principals of universal egalitarianism found in law and morality. On the other side, secular common-sense should not position itself as a judge of truths of faith, despite there being evidence that common-sense only considers a statement to be rational as far as that statement can be translated in an open discourse for the public." (Habermas, 2008)

A reformulation of the relationship between religion and common-sense can lead to an understanding of respectful tolerance based upon harmonizing of universal moral values and the valuing of tolerance towards ethical diversity (Habermas, 2005). Habermas makes use of the term, "transposing or translating" religious 
argumentations in public political discourse. This is a mutual learning process, meaning that not only citizens who hold religious beliefs have a responsibility to translate their views into a secular language so as to avoid unfair social domination over illegitimate beliefs. Those holding secular convictions also have a responsibility to respect a religious position, and in the mutual learning process, should also grasp the meaning of the following: "A liberal political culture can expect secular citizens to take an active role in translating relevant religious contributions in the language of public reason" (Habermas, 2005).

This call of Habermas is formulated in the context of a secular liberal state where religion is often not taken seriously in the public forum, by secular thinkers. In the Indonesian context, this is not particularly relevant as for a long time there has been an excess of religion in the public arena, which endangers the standing of tolerance and pluralism as the foundation of life, which is on a level ground, and is free and democratic. What is needed in Indonesia is a willingness on the part of religions to listen to the voice of common-sense, and particular public common-sense, so that the religions truly radiate humanity and not the opposite whereby humanity is sacrificed on the altar of religious doctrines.

\section{Religion and the Danger of the Privatization of Faith}

The condition of the post-secular society is a wake-up call to religions and especially to the Catholic Church to respond to the tendency of secularism in modern society which domesticates religion or even puts God into a private box (Crockett, 2015). God who is thus boxed-in is a God who is not given an opportunity to disturb or challenge one's personal comfort zone (Sunarko, 2016). Here faith or church-centred life is viewed exclusively as something personal, with no socio-political relevance.

A distilled spirituality becomes a personal, ritualistic piety, minus social involvement and social responsibility (Carr, 2012). Hence the following paradoxical phenomenon arises, which is not 
surprising: People can faithfully take part in worship while at the same time be corrupt. They can go on a pilgrimage to the Holy Land or give a donation towards the building of a church or house of worship, using money obtained from corrupt practices, such as from an illegal mine that was destroying nature. When this happens a church or religion is no more than a balm which soothes the soul, as described by the theologian, J.B. Metz: "This kind of religion isn't much more than a name for a dream of happiness without suffering, a mystical obsession of the soul, or an ethical-psychological fantasy of human sinlessness." (Metz, 1994)

Pope Franscis says something similar to the Catholic faithful in his apostolic address, "Evangelii Gaudium" (Fransiskus, 2014). The Pope emphasizes the importance of the political aspect and social involvement in faith. Such an involvement must be born out of a relationship with God that emanates from prayer. Regarding the importance of prayer, Pope Francis writes, "The Church truly needs a deep breath of prayer. I am truly joyful when prayer groups and scripture sharing groups, and adoration of the Blessed Sacrament, flourish in all the Church's institutions (Fransiskus, 2014).

However, prayer is just one aspect of the spiritual life. Prayer must be expressed in acts of charity: "There is always a risk that moments of prayer can become a reason not to offer one's personal life to mission. A life-style that stresses private piety can lead the Christian faithful into adopting a false spirituality (Fransiskus, 2014). A prayer life without actions of charity and social involvement is a form of escapism. Because of this, the Pope underlines the importance of the political aspect of faith. Politics here means the struggle to make real the Kingdom of God that liberates (Crockett, 2015).

The Church cannot withdraw from the world, but must go right into it. The Church must be missionary. This means that the Church must proclaim the Gospel that liberates. The Church must be able to hear the cry of those imprisoned. The Church must heal the sick, be an advocate for those whose rights have been trampled on. The Church must bring down the proud-hearted from their 
thrones of power, including the thrones of economic power which have been built upon pyramids of human sacrifice.

The missionary Church that is involved has a theological basis in the incarnation, whereby God became a human being and took on a role in human history. In the incarnation God showed a radical solidarity with humanity, especially with the poor, and victims who have been marginalized. God left God's grandeur and entered the world of fragility of human, mortal history. The involvement of God in human history has been to raise the standing of humankind and to radiate the light of hope.

The political dimension of faith is rooted in solidarity with God in the person of Jesus. This solidarity must become the basis for the Church's solidarity with the poor. The poor and marginalized get priority not because they are true, but because they suffer. Ethically, those who suffer have a right to receive special attention. Pope Francis stresses the importance of the priority given by the Church to the poor. This is not just because the poor need help, but primarily because the poor are able to convert the Church from being triumphant to being a Church that serves and dialogues. Because of this, the poor have a primary theological place. Secondly, they are regarded from sociological and political perspectives. "Because of this, I idealize a Church which is poor for the poor" (Fransiskus, 2014). Every community in the Church which forgets the poor is in danger of destroying itself. Because if it doesn't prioritize the poor, it's religious activities will not bear fruit, and will get carried away by the opium of the spirituality of well-being.

\section{CONCLUSIONS}

Post-secularism came to birth as religions took their place in the public forum. It is the antithesis of the secularist viewpoint which is characterized by the marginalizing of religion to the private domain. The appearance of religion in the public arena has two faces. On the one side, one can see a hard face which reflects various forms of religious fundamentalism and terrorism. On the other side, 
religion proposes a moral potentiality which can resolve a variety of public ethical issues such as euthanasia, abortion and the crisis of meaning which modern society is dealing with.

For religion, post-secularism presents a number of challenges and also opportunities at the same time. In the public arena, religion faces a pluralist society. This means that religion must translate its pre-political messages into an inter-religious language. Besides this, religion must promote tolerance as a virtue of democracy. Also, post secularism can assist religion to overcome a tendency to domesticate faith, making it a solely private affair. Faith is not just a matter of ritualistic piety, but it also has social-political consequences which prioritizes care for the marginalized.

Post-secularism provides also a paradigm in developing dialogue between religion and philosophy. On the one hand, postsecularism opens up opportunity for religion to be actively involved in public sphere. However, public sphere generally surfaces as a plural arena. Therefore, philosophy can play a fundamental role to help religion transpose its primordial or pre-political messages into political propositions that can be interreligiously and interculturally comprehended (Madung, 2021). On the other hand, religion can challenge and question a kind of philosophy trapped in shallow secularism that closes itself to religious or transcendental questions. By this means, philosophy and religion can develop a fruitful learning process for a better humanity.

\section{REFERENCES}

Carr, D. (2012). Post-secularism, religious knowledge and religious education. Journal of Beliefs and Values, 33(2), 157-168. http://dx.doi.org/10.1080/13617672.2012.694059

Crockett, C. (2015). Post-Secularism, Secular Theology, and the Names of the Real. Dialog: A Journal of Theology, 54(4), 317-326

Dew, R. (2019). Beyond Secular Borders: Habermas's Communicative Ethic and the Need for Post-Secular Understanding. Critical Horizons, 20(4), 317-332. https://doi.org/10.1080/14409917.2019.1616483 
Eicher, P. (Ed.). (1991). Neues Handbuch theologischer Grundbegriffe. Vol 4. München: Kösel Verlag.

Fransiskus. (2014). Evangelii Gaudium. Sukacita Injili (EG). Terj. F.X. Adisusanto SJ dan Bernadeta Harini Tri Prasasti. Jakarta: Dokpen KWI.

Habermas, J. (1996). Die Einbeziehung des Anderen. Frankfurt am Mein: Suhrkamp Verlag.

Habermas, J. (2001). Glaube und Wissen. Frankfurt am Mein: Suhrkamp.

Habermas, J. (2005). Zwischen Naturalismus und Religion. Frankfurt am Mein: Suhrkamp Verlag.

Habermas, J. (2008). Ein Bewußtsein von dem, was fehlt, edited by Michael Reder/Joseph Schmidt. Frankfurt am Mein: Suhrkamp Verlag.

Habermas, J. (2020). Auch eine Geschichte der Philosophie: Vernünftige Freiheit. Spuren des Diskurses über Glauben und Wissen, Vol 2. Frankfurt am Main: Suhrkamp Verlag.

Hadiz, V. R. (2017). Indonesian Politics in 2017. Indonesias Year of Democratic Setbacks: Towards a New Phase of Deepenig Illiberalism? Bulletin of Indonesian Economic Studies. 53(3), 261278.

Küng H. (2008). "Leitlinien zum Weiterdenken", Hans-Martin Schoenherr-Mann, Miteinder Leben Lernen. München: Piper Verlag.

Lutz-Bachmann, M. (2015). “Die postsäkulare Konstelation: Öffentliche Vernunft, Religion und Wissenschaft", Mathias Lutz-Bachmann (Ed.), Postsäkularismus. Zur Diskussion eines umstrittenen Begriffs. Frankfurt am Mein: Campus Verlag.

Lübbe, H. (2003). Säkularisierung. Geschichte eines ideenpolitischen Begriffs. Freiburg/München: Verlag Karl Alber.

Madung, O. G. (2010). “Etos Global dan Dialog Peradaban”, Kompas. Madung, O. G. (2017, April 11). Teologi Maut Vs Teologi Pascasekular. Media Indonesia. https://mediaindonesia.com/read/detail/100298-teologi-mautvs-teologi-pascasekuler 
Madung, O. G. (2020). “Kebebasan Beragama atau Berkeyakinan di Indonesia: Perspektif Diskursus Liberalisme Versus Multikulturalisme", dalam: Al Khanif et al. (Eds), Kebebasan Beragama atau Berkeyakinan di Indonesia. Perspektif Filosofis, Hukum, dan Politik. Malang: Intrans Publishing.

Madung, O. G. (2021). Constructing Modern Indonesia Based on Pancasila in Dialogue with the Political Concepts Underlying the Idea of Human Rights. Journal of Southeast Asian Human Rights. 5(1), $1-24$.

https://jurnal.unej.ac.id/index.php/ISEAHR/article/view/2025 $\underline{8 / 9881}$

Metz, J. B. (1994). „Gotteskrise. Versuch zur geistigen Situation der Zeit", Diagnosen zur Zeit (mit Beiträgen von Johann Baptist Metz, Jürgen Habermas u.a.). Düsseldorf: Patmos Verlag.

Miller, K. D. (2019). Responding to Fundamentalism: Secularism od Humble Faith? Academy of Management Perspectives, 33(3), 307322. https://doi.org/10.5465/amp.2017.0101

Rahman, D. A. (2019, March 31). "Setara Institute: 2018, 202 Pelanggaran Kebebasan Beragama dan Berkeyakinan Terjadi", Kompas.

https://nasional.kompas.com/read/2019/03/31/16014091/setara -institute-2018-202-pelanggaran-kebebasan-beragama-danberkeyakinan?page $=$ all

Seljak, D. (2016). Post-Secularism, Multiculturalism, Human Rights, and Religion in Ontario. Studies in Religion, 45(4), 542-565. DOI: 10.1177/0008429815596547

Sunarko, A. (2016). "Berteologi bagi Agama di Zaman PostSekular", DISKURSUS 15 (1).

Ulfig, A. (1999). Lexikon der philosophischen Begriffe. Wiesbaden: Fourier Verlag.

Weber, M. (1988). "Die protestantische Ethik und der Geist des Kapitalismus", Gesammelte Aufsätze zur Religionssoziologie. Tübingen: Mohr Siebeck Verlag. 